\title{
A Pore-Forming Tripeptide as an Extraordinarily Active Anion Channel
}

Fei Zeng, ${ }^{\dagger}$ Fang Liu, ${ }^{\dagger}$ Lin Yuan, ${ }^{\dagger}$ Shaoyuan Zhou, ${ }^{\ddagger}$ Jie Shen,${ }^{\S}$ Ning Li, ${ }^{\S}$ Haisheng Ren ${ }^{*}$ and and Huaqiang Zeng*,

${ }^{\dagger}$ College of Chemistry and Bioengineering, Hunan University of Science and Engineering, Yongzhou, Hunan, China 425100b

${ }^{\ddagger}$ College of Chemical Engineering, Sichuan University, Chengdu, China 610065. E-mail:

renhs@scu.edu.cn

$\S$ NanoBio Lab, 31 Biopolis Way, The Nanos, Singapore 138669. E-mail: hqzeng@nbl.a-star.edu.sg; Tel: $+65-6824-7115$

Corresponding Authors: renhs@scu.edu.cn and hqzeng@ibn.a-star.edu.sg

1. General Remarks.

2. Synthetic Scheme and Structures of di- and tripeptides. .53

3. Experimental Procedures and Compound Characterizations

4. Experimental Methods for Ion Transport Study .S6

5. Figure S1. Determination of $\mathrm{Cl}^{-}$-transporting $E C_{50}$ for $6 \mathrm{~L}_{2} 10$ and $6 \mathrm{~L}_{3} 10$ .$S 11$

6. Figures S2 and S3. CF Dye Leaking Assay .$S 12$

7. Figure S4. Ion Transport Mechanism Study .$S 13$

8. Figures S5. $E C_{50}$ Determination for $6 \mathrm{~L}_{2} 10$ toward other anions. .514

9. Figures $S 6 . E C_{50}$ Determination for $6 \mathrm{~L}_{3} 10$ toward other anions. .515

10. Details in Molecular Modeling .516

11. ${ }^{1} \mathrm{H} /{ }^{13} \mathrm{C}$ NMR Spectra .518 


\section{General Remarks}

All the reagents were obtained from commercial suppliers and used as received unless otherwise noted. Aqueous solutions were prepared from MilliQ water. The organic solutions from all liquid extractions were dried over anhydrous $\mathrm{Na}_{2} \mathrm{SO}_{4}$ for a minimum of 15 minutes before filtration. Flash column chromatography was performed using pre-coated $0.2 \mathrm{~mm}$ silica plates from Selecto Scientific. Chemical yield refers to pure isolated substances. ${ }^{1} \mathrm{H}$ and ${ }^{13} \mathrm{C}$ NMR spectra were recorded on either a Bruker ACF-400 spectrometer. The solvent signal of $\mathrm{CDCl}_{3}$ was referenced at $\delta=7.26 \mathrm{ppm}$. Coupling constants ( $J$ values) are reported in Hertz $(\mathrm{Hz}) .{ }^{1} \mathrm{H}$ NMR data are recorded in the order: chemical shift value, multiplicity (s, singlet; $d$, doublet; $t$, triplet; q, quartet; m, multiplet; br, broad), number of protons that gave rise to the signal and coupling constant, where applicable. ${ }^{13} \mathrm{C}$ spectra are proton-decoupled and recorded on Bruker ACF400 (400 MHz). The solvent, $\mathrm{CDCl}_{3}$, was referenced at $\delta=77$ ppm. $\mathrm{CDCl}_{3}$ (99.8\%-Deuterated) was purchased from Aldrich and used without further purification. Mass spectra were acquired with Shimazu LCMS-2010EV. 
Synthetic Scheme and Chemical Structure of dipeptide

$\underset{\text { C6-Leu-COOH }}{\mathrm{NH}_{\mathbf{2}} \text {-Leu-C10 }}$

Synthetic Scheme and Chemical Structures of tripeptide

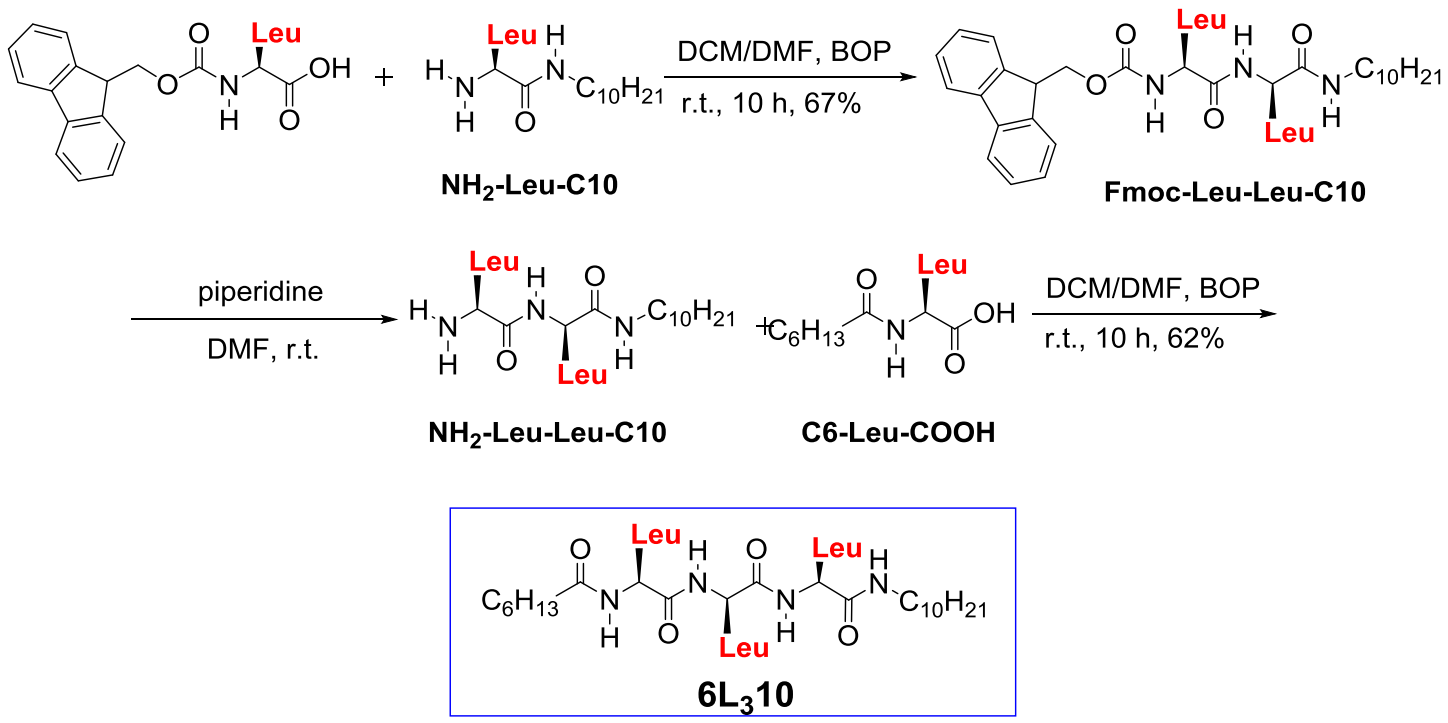

For synthesis of starting materials $\mathbf{N H}_{2}-\mathbf{A A}-\mathrm{Cn}$, see Ren, C. L.; Zeng, F.; Shen, J.; Chen, F.; Arundhati, R.; Zhou, S.; Ren, H.; Zeng, H. Q. J. Am. Chem. Soc. 2018, 140, 8817-8826.

$6 \mathbf{L}_{2} 10$

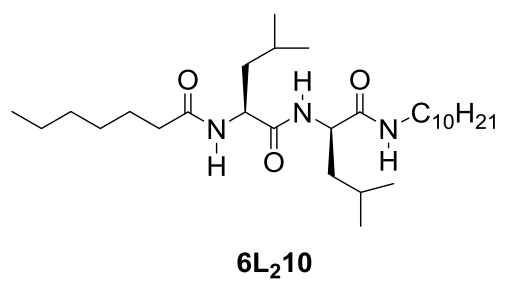

C6-Leu-COOH (243 mg, $1.0 \mathrm{mmol}$ ), $\mathbf{N H}_{2}$-Leu-C10 (270 mg, $1.0 \mathrm{mmol})$ and BOP (486 mg, $1.1 \mathrm{mmol})$ were dissolved in $\mathrm{CH}_{2} \mathrm{Cl}_{2} / \mathrm{DMF}(8 \mathrm{~mL}: 2 \mathrm{~mL}$ ) to which diisopropylamine $(0.39 \mathrm{ml}, 2.2 \mathrm{mmol})$ was added. The reaction mixture was stirred for 10 hours at room temperature. Solvent was removed in vacuo and the crude product was purified by flash column chromatography $(\mathrm{MeOH}$ : $\left.\mathrm{CH}_{2} \mathrm{Cl}_{2}=1: 50, \mathrm{v}: \mathrm{v}\right)$ to afford the pure product $\mathbf{6} \mathbf{L}_{\mathbf{2}} \mathbf{1 0}$ as a white solid. Yield: $421 \mathrm{mg}$, 85\%. ${ }^{1} \mathrm{H}$ NMR (400 MHz, $\left.\mathrm{CDCl}_{3}\right) \delta 7.79(\mathrm{~d}, J=8.2 \mathrm{~Hz}, 1 \mathrm{H}), 7.29(\mathrm{~d}, J=4.5 \mathrm{~Hz}, 1 \mathrm{H})$, 
$7.11(\mathrm{~d}, J=8.3 \mathrm{~Hz}, 1 \mathrm{H}), 4.74(\mathrm{dd}, J=14.7,8.1 \mathrm{~Hz}, 1 \mathrm{H}), 4.58(\mathrm{dd}, J=15.4,7.8 \mathrm{~Hz}$, $1 \mathrm{H}), 3.21(\mathrm{dtd}, J=19.0,13.3,6.0 \mathrm{~Hz}, 2 \mathrm{H}), 2.37-2.15(\mathrm{~m}, 2 \mathrm{H}), 1.82-1.38(\mathrm{~m}, 11 \mathrm{H})$, $1.39-1.19(\mathrm{~m}, 19 \mathrm{H}), 0.99-0.79(\mathrm{~m}, 18 \mathrm{H}) .{ }^{13} \mathrm{C} \mathrm{NMR}\left(101 \mathrm{MHz}, \mathrm{CDCl}_{3}\right) \delta 173.4$, 172.5, 172.0, 51.8, 51.4, 41.8, 41.0, 39.6, 36.3, 36.1, 31.9, 31.5, 29.6, 29.4, 29.4, 29.4, 27.0, 25.6, 25.4, 24.9, 24.9, 24.8, 22.9, 22.8, 22.7, 22.6, 22.6, 22.5, 22.5, 22.0, 14.1, 14.0. HRMS-ESI: calculated for $[\mathrm{M}+\mathrm{H}]^{+}\left(\mathrm{C}_{29} \mathrm{H}_{58} \mathrm{O}_{3} \mathrm{~N}_{3}\right): \mathrm{m} / z$ 496.4478, found: $\mathrm{m} / \mathrm{z}$ 496.4486.

\section{Fmoc- $\mathbf{L}_{2}-10$}

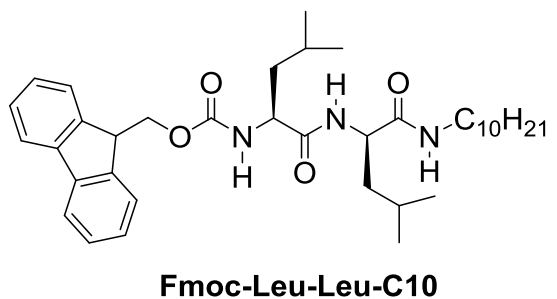

Fmoc-Leu-OH (353 mg, $1.0 \mathrm{mmol}$ ), NH$_{2}$-Leu-C10 $(270 \mathrm{mg}, 1.0 \mathrm{mmol})$ and BOP $(486 \mathrm{mg}, 1.1 \mathrm{mmol})$ were dissolved in $\mathrm{CH}_{2} \mathrm{Cl}_{2} / \mathrm{DMF}(8 \mathrm{~mL}: 2 \mathrm{~mL}$ ) to which diisopropylamine $(0.39 \mathrm{ml}, 2.2 \mathrm{mmol})$ was added. The reaction mixture was stirred for 10 hours at room temperature. Solvent was removed in vacuo and the crude product was purified by flash column chromatography (MeOH: $\mathrm{CH}_{2} \mathrm{Cl}_{2}=1: 60$, v:v) to afford the pure product Fmoc-Leu-Leu-C10 as a white solid. Yield: $406 \mathrm{mg}, 67 \%$. ${ }^{1} \mathrm{H}$ NMR $\left(400 \mathrm{MHz}, \mathrm{CDCl}_{3}\right) \delta 7.74(\mathrm{dd}, J=12.2,4.7 \mathrm{~Hz}, 2 \mathrm{H}), 7.60-7.51(\mathrm{~m}, 2 \mathrm{H}), 7.46-7.18$ (m, 5H), 6.99 (d, $J=3.9 \mathrm{~Hz}, 1 \mathrm{H}), 6.62(\mathrm{~s}, 1 \mathrm{H}), 5.66(\mathrm{~d}, J=7.2 \mathrm{~Hz}, 1 \mathrm{H}), 4.54-4.24$ $(\mathrm{m}, 4 \mathrm{H}), 4.16(\mathrm{t}, J=7.0 \mathrm{~Hz}, 1 \mathrm{H}), 3.32-3.06(\mathrm{~m}, 2 \mathrm{H}), 1.71-1.41(\mathrm{~m}, 8 \mathrm{H}), 1.28-$ $1.15(\mathrm{~m}, 13 \mathrm{H}), 0.90(\mathrm{dtd}, J=13.9,6.8,2.9 \mathrm{~Hz}, 15 \mathrm{H}) .{ }^{13} \mathrm{C} \mathrm{NMR}\left(101 \mathrm{MHz}, \mathrm{CDCl}_{3}\right) \delta$ $172.6,171.8,156.3,143.8,143.7,141.3,127.8,127.1,125.1,125.0,120.0,112.0$, 67.1, 53.6, 51.9, 47.1, 41., 40.9, 39.8, 31.9, 29.6, 29.4, 29.4, 29.3, 26.9, 24.9, 24.8, 23.0, 22.8, 22.7, 22.2, 22.0, 14.2. HRMS-ESI: calculated for $[\mathrm{M}+\mathrm{H}]^{+}\left(\mathrm{C}_{37} \mathrm{H}_{56} \mathrm{O}_{4} \mathrm{~N}_{3}\right)$ : $\mathrm{m} / \mathrm{z}$ 606.4271, found: $\mathrm{m} / \mathrm{z} 606.4280$.

\section{$6 \mathrm{~L}_{3} 10$}

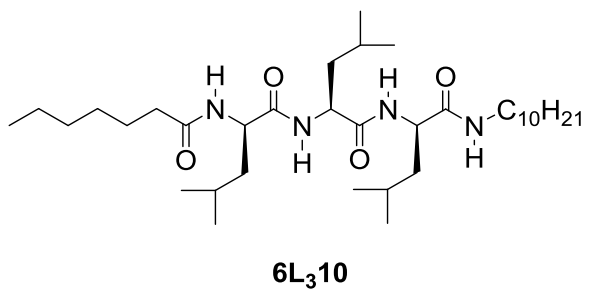

To a solution of Fmoc- $\mathbf{L}_{\mathbf{2}}-\mathbf{1 0}(2.42 \mathrm{~g}, 4 \mathrm{mmol})$ in $\mathrm{CHCl}_{3}(20 \mathrm{~mL})$ was added piperidine $(2.0 \mathrm{~mL})$, and reaction was allowed to stir at room 
temperature for $12 \mathrm{~h}$. The solvent was then removed in vacuo and the crude product was purified by flash column chromatography ( $\mathrm{MeOH}: \mathrm{CH}_{2} \mathrm{Cl}_{2}=1: 20$, v:v) to yield product $\mathbf{N H}_{2}$-Leu-Leu-C10. C6-Leu-COOH (243 mg, $1.0 \mathrm{mmol}$ ), $\mathbf{N H}_{2}$-Leu-LeuC10 (383 mg, $1.0 \mathrm{mmol}$ ) and BOP (486 mg, $1.1 \mathrm{mmol}$ ) were dissolved in $\mathrm{CH}_{2} \mathrm{Cl}_{2} / \mathrm{DMF}$ (8 $\mathrm{mL}: 2 \mathrm{~mL}$ ) to which diisopropylamine $(0.39 \mathrm{ml}, 2.2 \mathrm{mmol})$ was added. The reaction mixture was stirred for 10 hours at room temperature. Solvent was removed in vacuo and and the crude product was dissolved in $\mathrm{MeOH}(30 \mathrm{~mL})$, which was recrystallized from acetonitrile to yield the pure product $6 \mathbf{L}_{\mathbf{3}} \mathbf{1 0}$ as a white solid. Yield: 377mg, 62\%. ${ }^{1} \mathrm{H}$ NMR (400 MHz, CD 3 OD) $\delta 4.60$ (s, 3H), 4.29 (ddd, $J$ $=9.1,6.2,3.5 \mathrm{~Hz}, 3 \mathrm{H}), 3.12(\mathrm{t}, J=6.9 \mathrm{~Hz}, 2 \mathrm{H}), 2.27-2.10(\mathrm{~m}, 3 \mathrm{H}), 1.70-1.37(\mathrm{~m}$, $13 \mathrm{H}), 1.34-1.15(\mathrm{~m}, 18 \mathrm{H}), 0.98-0.76(\mathrm{~m}, 22 \mathrm{H}) .{ }^{13} \mathrm{C} \mathrm{NMR}\left(101 \mathrm{MHz}, \mathrm{CD}_{3} \mathrm{OD}\right) \delta$ 175.3, 173.9, 173.1, 173.1, 52.2, 52.0, 51.8, 40.50, 40.2, 40.0, 39.0, 35.4, 31.7, 31.4, 29.4, 29.3, 29.1, 29.1, 28.9, 28.6, 26.5, 25.5, 24.5, 24.5, 24.5, 22.4, 22.3, 22.1, 22.1, 22.0, 20.7, 20.6, 20.5, 13.1, 13.0. HRMS-ESI: calculated for $[\mathrm{M}+\mathrm{H}]^{+}\left(\mathrm{C}_{35} \mathrm{H}_{69} \mathrm{O}_{4} \mathrm{~N}_{4}\right)$ : $\mathrm{m} / z$ 609.5319, found: $m / z 609.5329$. 


\section{Experimental methods for ion transport study}

Ion transport study using the HPTS assay and $E C_{50}$ measurements using the Hill analysis. Egg yolk L- $\alpha$-phosphatidylcholine (EYPC, $1 \mathrm{ml}, 25 \mathrm{mg} / \mathrm{mL}$ in $\mathrm{CHCl}_{3}$, Avanti Polar Lipids, USA) and $\mathrm{MeOH}(1 \mathrm{~mL})$ were mixed in a round-bottom flask. The mixed solvents were removed under reduced pressure at $40{ }^{\circ} \mathrm{C}$. After drying the resulting film under high vacuum overnight at room temperature, the film was hydrated with 4-(2-hydroxyethyl)-1piperazine-ethane sulfonic acid (HEPES) buffer solution $(1 \mathrm{~mL}, 10 \mathrm{mM}$ HEPES, $100 \mathrm{mM}$ $\mathrm{NaCl}, \mathrm{pH}=7.0$ ) containing a $\mathrm{pH}$ sensitive dye 8-hydrox-ypyrene-1,3,6-trisulfonic acid (HPTS, $1 \mathrm{mM}$ ) at room temperature for 60 minutes to give a milky suspension. The mixture was then subjected to 12 freeze-thaw cycles: freezing in liquid $\mathrm{N}_{2}$ for 1 minute and heating $37{ }^{\circ} \mathrm{C}$ water bath for 1.5 minutes. The vesicle suspension was extruded through polycarbonate membrane $(0.1 \mu \mathrm{m})$ to produce a homogeneous suspension of large unilamellar vesicles (LUVs) of about $120 \mathrm{~nm}$ in diameter with HPTS encapsulated inside. The untrapped HPTS dye was separated from the LUVs by using size exclusion chromatography (stationary phase: Sephadex G-50, GE Healthcare, USA, mobile phase: HEPES buffer with $100 \mathrm{Mm} \mathrm{NaCl}$ at $\mathrm{pH} 7.0$ ) and diluted with the mobile phase to yield $12.8 \mathrm{~mL}$ of $2.5 \mathrm{mM}$ lipid stock solution. This HPTS-containing LUV suspension $(25 \mu \mathrm{L}, 2.5 \mathrm{mM})$ was added to a HEPES buffer solution $(1.93 \mathrm{~mL}, 10 \mathrm{mM}$ HEPES, $100 \mathrm{mM} \mathrm{NaCl}$ at $\mathrm{pH}=8.0$ ) to create a $\mathrm{pH}$ gradient for ion transport study. A solution of channel molecules in DMSO was then injected into the suspension under gentle stirring. Upon the addition of channels, the emission of HPTS was immediately monitored at $510 \mathrm{~nm}$ with excitations at both 460 and $403 \mathrm{~nm}$ recorded simultaneously for 300 seconds using fluorescence spectrophotometer (Hitachi, Model F-7100, Japan). At $t=300 \mathrm{~s}$, an aqueous solution of Triton X-100 (20 $\mu \mathrm{L}, 20 \% \mathrm{v} / \mathrm{v})$ was immediately added to achieve the maximum change in dye fluorescence emission intensity. After subtracting background intensity at $\mathrm{t}=0$, the final transport trace was obtained as a ratiometric value of $\mathrm{I}_{460} / \mathrm{I}_{403}$ and normalized based on the ratiometric value of $\mathrm{I}_{460} / \mathrm{I}_{403}$ after addition of triton at $t=300 \mathrm{~s}$. The fractional changes $R_{C l}$ was calculated for each curve using the normalized value of $\mathrm{I}_{460} / \mathrm{I}_{403}$ at $t=300 \mathrm{~s}$ before the addition of triton, with ratiometric value of $\mathrm{I}_{460} / \mathrm{I}_{403}$ at $\mathrm{t}=0 \mathrm{~s}$ as $0 \%$ and that of $\mathrm{I}_{460} / \mathrm{I}_{403}$ at $\mathrm{t}=$ $300 \mathrm{~s}$ (obtained after addition of triton) as $100 \%$. Fitting the fractional transmembrane activity $R_{C l}$ vs channel concentration using the Hill equation: $Y=1 /\left(1+\left(E C_{50} /[C]\right)^{n}\right)$ gave the Hill coefficient $n$ and $E C_{50}$ values.

Membrane leaking and pore size determination using $\mathbf{C F}$ dye. Egg yolk L- $\alpha$ phosphatidylcholine (EYPC, $1 \mathrm{ml}, 25 \mathrm{mg} / \mathrm{mL}$ in $\mathrm{CHCl}_{3}$, Avanti Polar Lipids, USA) and $\mathrm{MeOH}(1 \mathrm{~mL})$ were mixed in a round-bottom flask. The mixed solvents were removed under reduced pressure at $40{ }^{\circ} \mathrm{C}$. After drying the resulting film under high vacuum overnight at room temperature, the film was hydrated with HEPES buffer solution $(1 \mathrm{~mL}, 10 \mathrm{mM}$ HEPES, $100 \mathrm{mM} \mathrm{NaCl}, \mathrm{pH}=7.5)$ containing a 5(6)-fluorescein $(\mathrm{CF}, 50 \mathrm{mM})$ at room temperature for 60 minutes to give a milky suspension. The mixture was then subjected to 12 freeze-thaw cycles: freezing in liquid $\mathrm{N}_{2}$ for 1 minute and heating at $37{ }^{\circ} \mathrm{C}$ in water bath for 1.5 minutes. The vesicle suspension was extruded through polycarbonate membrane $(0.1 \mu \mathrm{m})$ to produce a homogeneous suspension of large unilamellar vesicles (LUVs) of about $120 \mathrm{~nm}$ in diameter 
with CF encapsulated inside. The free unencapsulated CF dye was separated from the LUVs by using size exclusion chromatography (stationary phase: Sephadex G-50, GE Healthcare, USA, mobile phase: HEPES buffer with $100 \mathrm{mM} \mathrm{NaCl}$ ) and diluted with the mobile phase to yield $12.8 \mathrm{~mL}$ of $2.5 \mathrm{mM}$ lipid stock solution.

The CF-containing LUV suspension $(25 \mu \mathrm{L}, 2.5 \mathrm{mM}$ in $10 \mathrm{mM}$ HEPES buffer containing $100 \mathrm{mM} \mathrm{NaCl}$ at $\mathrm{pH}=7.5)$ was added to a HEPES buffer solution $(1.93 \mathrm{~mL}, 10 \mathrm{mM}$ HEPES, $100 \mathrm{mM} \mathrm{NaCl}$ at $\mathrm{pH}=7.5$ ) to create a concentration gradient for $\mathrm{CF}$ dye transport study. A solution of $6 \mathbf{L}_{3} \mathbf{1 0}(2.5 \mu \mathrm{M})$ or natural poreforming peptide Melittin in DMSO at different concentrations was then injected into the suspension under gentle stirring. Upon the addition of pore-forming monopeptide molecules, the emission of CF was immediately monitored at $517 \mathrm{~nm}$ with excitations at $492 \mathrm{~nm}$ for 300 seconds using fluorescence spectrophotometer (Hitachi, Model F-7100, Japan) after which time an aqueous solution of Triton X-100 (20 $\mu \mathrm{L}$, $20 \% \mathrm{v} / \mathrm{v}$ ) was immediately added to completely destroy the chloride gradient. The final transport trace was obtained by normalizing the fluorescence intensity using the equation of $I_{f}$ $=\left[\left(I_{t}-I_{0}\right) /\left(I_{l^{-}} I_{0}\right)\right]$ where, $I_{f}=$ Fractional emission intensity, $I_{t}=$ Fluorescence intensity at time $t, I_{1}=$ Fluorescence intensity after addition of Triton X-100, and $I_{0}=$ Initial fluorescence intensity .

The HPTS assay for cation selectivity. The HPTS-containing LUV suspension $(25 \mu \mathrm{L}, 2.5$ $\mathrm{mM}$ in $10 \mathrm{mM}$ HEPES buffer containing $100 \mathrm{mM} \mathrm{NaCl}$ at $\mathrm{pH}=7.0$ ) was added to a HEPES buffer solution $\left(1.93 \mathrm{~mL}, 10 \mathrm{mM}\right.$ HEPES, $100 \mathrm{mM} \mathrm{MCl}$ at $\mathrm{pH}=8.0$, where $\mathrm{M}^{+}=\mathrm{Li}^{+}, \mathrm{Na}^{+}, \mathrm{K}^{+}$, $\mathrm{Rb}^{+}$, and $\mathrm{Cs}^{+}$) to create a $\mathrm{pH}$ gradient for ion transport study. A solution of peptide molecules such as $6 \mathbf{L}_{3} \mathbf{1 0}$ at specified concentrations in DMSO was then injected into the suspension under gentle stirring. Upon the addition of channels, the emission of HPTS was immediately monitored at $510 \mathrm{~nm}$ with excitations at both 460 and $403 \mathrm{~nm}$ recorded simultaneously for 300 seconds using fluorescence spectrophotometer (Hitachi, Model F-7100, Japan) after which time an aqueous solution of Triton X-100 (20 $\mu \mathrm{L}, 20 \% \mathrm{v} / \mathrm{v})$ was immediately added to achieve the maximum change in dye fluorescence emission. The final transport trace was obtained as a ratiometric value of $\mathrm{I}_{460} / \mathrm{I}_{403}$ and normalized based on the ratiometric value of $\mathrm{I}_{460} / \mathrm{I}_{403}$ after addition of triton.

Sulphate-containing HPTS assay for cation selectivity. Egg yolk L- $\alpha$ phosphatidylcholine (EYPC, $1 \mathrm{ml}, 25 \mathrm{mg} / \mathrm{mL}$ in $\mathrm{CHCl}_{3}$, Avanti Polar Lipids, USA) solvents were removed under reduced pressure at room temperature. After drying the resulting film under high vacuum overnight at room temperature, the film was hydrated with 4-(2hydroxyethyl)-1-piperazine-ethane sulfonic acid (HEPES) buffer solution $(1.0 \mathrm{~mL}, 10 \mathrm{mM}$ HEPES, $\mathrm{pH}=7.0$ ) containing a $\mathrm{pH}$ sensitive dye 8-hydrox-ypyrene-1,3,6-trisulfonic acid (HPTS, $1 \mathrm{mM}$ ) in thermostatic shaker-incubator at $37{ }^{\circ} \mathrm{C}$ for 2 hours to give a milky suspension. The mixture was then subjected to 10 freeze-thaw cycles: freezing in liquid $\mathrm{N}_{2}$ for 1 minute and heating at $55{ }^{\circ} \mathrm{C}$ for 2 minutes. The vesicle suspension was extruded through polycarbonate membrane $(0.1 \mu \mathrm{m})$ to produce a homogeneous suspension of large unilamellar vesicles (LUVs) of about $100 \mathrm{~nm}$ in diameter with HPTS encapsulated inside. The unencapsulated HPTS dye was separated from the LUVs by using size exclusion 
chromatography (stationary phase: Sephadex G-50, GE Healthcare, USA, mobile phase: HEPES buffer with, $\mathrm{pH}=7.0$ ) and diluted with the mobile phase to yield $13 \mathrm{~mL}$ of $2.5 \mathrm{mM}$ lipid stock solution.

The HPTS-containing LUV suspension $(25 \mu \mathrm{L}, 2.5 \mathrm{mM}$ in $10 \mathrm{mM}$ HEPES buffer, $\mathrm{pH}=7.0)$ was added to a HEPES buffer solution (1.95 mL, $10 \mathrm{mM}$ HEPES, $200 \mathrm{mM} \mathrm{M}_{2} \mathrm{SO}_{4}$ at $\mathrm{pH}=7.0$, where $\mathrm{M}^{+}=\mathrm{Li}^{+}, \mathrm{Na}^{+}, \mathrm{K}^{+}, \mathrm{Rb}^{+}$and $\mathrm{Cs}^{+}$) for ion transport study. A solution of channel molecule $6 \mathbf{L}_{3} \mathbf{1 0}$ at a final concentration of $4 \mu \mathrm{M}$ (or gramicidin $\mathrm{A}$ at $1 \mathrm{nM}$ ) in DMSO was then injected into the suspension under gentle stirring. Upon the addition of channels, the emission of HPTS was immediately monitored at $510 \mathrm{~nm}$ with excitations at both 460 and $403 \mathrm{~nm}$ recorded simultaneously for 300 seconds using fluorescence spectrophotometer (Hitachi, Model F-7100, Japan) after which time an aqueous solution of Triton X-100 (20 $\mu \mathrm{L}$, $20 \% \mathrm{v} / \mathrm{v})$ was immediately added to achieve the maximum change in dye fluorescence emission. The final transport trace was obtained as a ratiometric value of $\mathrm{I}_{460} / \mathrm{I}_{403}$ and normalized based on the ratiometric value of $\mathrm{I}_{460} / \mathrm{I}_{403}$ after addition of triton.

Chloride transport using the SPQ Assay. Egg yolk L- $\alpha$-phosphatidylcholine (EYPC, $1 \mathrm{ml}$, $25 \mathrm{mg} / \mathrm{mL}$ in $\mathrm{CHCl}_{3}$, Avanti Polar Lipids, USA) and $\mathrm{MeOH}(1 \mathrm{~mL})$ were mixed in a roundbottom flask. The mixed solvents were removed under reduced pressure at $40{ }^{\circ} \mathrm{C}$. After drying the resulting film under high vacuum overnight at room temperature, the film was hydrated $\mathrm{NaNO}_{3}$ solution $(1 \mathrm{~mL}, 200 \mathrm{mM})$ containing a Cl -sensitive dye 6-methoxy-N-(3sulfopropyl)quinolinium (SPQ) $(0.5 \mathrm{mM})$ in thermostatic shaker-incubator at room temperature for 60 minutes to give a milky suspension. The mixture was then subjected to 12 freeze-thaw cycles: freezing in liquid $\mathrm{N}_{2}$ for 1 minute and heating at $37{ }^{\circ} \mathrm{C}$ in water bath for 1.5 minutes. The vesicle suspension was extruded through polycarbonate membrane $(0.1 \mu \mathrm{m})$ to produce a homogeneous suspension of large unilamellar vesicles (LUVs) of about $120 \mathrm{~nm}$ in diameter with SPQ encapsulated inside. The unencapsulated HPTS dye was separated from the LUVs by using size exclusion chromatography (stationary phase: Sephadex G-50, GE Healthcare, USA, mobile phase: $200 \mathrm{mM} \mathrm{NaNO}_{3}$ ) and diluted with the mobile phase to yield $12.8 \mathrm{~mL}$ of $2.5 \mathrm{mM}$ lipid stock solution.

The SPQ-containing LUV suspension $\left(25 \mu \mathrm{L}, 2.5 \mathrm{mM}\right.$ in $\left.200 \mathrm{mM} \mathrm{NaNO}_{3}\right)$ was added to a $\mathrm{NaCl}$ solution $(1.93 \mathrm{~mL}, 200 \mathrm{mM})$ to create an extravesicular chloride gradient. A solution of tripeptide molecule $\mathbf{6} \mathbf{L}_{3} \mathbf{1 0}$ in DMSO at different concentrations was then injected into the suspension under gentle stirring. Upon the addition of pore-forming monopeptide molecules, the emission of SPQ was immediately monitored at $430 \mathrm{~nm}$ with excitations at $360 \mathrm{~nm}$ for 300 seconds using fluorescence spectrophotometer (Hitachi, Model F-7100, Japan) after which time an aqueous solution of Triton X-100 (20 $\mu \mathrm{L}, 20 \% \mathrm{v} / \mathrm{v})$ was immediately added to completely destroy the chloride gradient. The final transport trace was obtained by normalizing the fluorescence intensity using the equation of $I_{f}=\left[\left(I_{t}-I_{1}\right) /\left(I_{0}-I_{1}\right)\right]$ where, $I_{f}=$ Fractional emission intensity, $I_{t}=$ Fluorescence intensity at time $t, I_{l}=$ Fluorescence intensity after addition of Triton X-100, and $I_{0}=$ Initial fluorescence intensity .

The HPTS assay in the presence of valinomycin (VA). The HPTS-containing LUV suspension $(25 \mu \mathrm{L}, 2.5 \mathrm{mM}$ in $10 \mathrm{mM}$ HEPES buffer containing $100 \mathrm{mM} \mathrm{NaCl}$ at $\mathrm{pH}=7.0)$ 
was added to a HEPES buffer solution (1.93 mL, $10 \mathrm{mM}$ HEPES, $100 \mathrm{mM} \mathrm{NaCl})$ to create a $\mathrm{pH}$ gradient for ion transport study. A solution of valinomycin $(0.1 \mathrm{pM})$ and $\mathbf{6} \mathbf{L}_{\mathbf{3}} \mathbf{1 0}(4.3 \mathrm{nM})$ in DMSO was then injected into the suspension under gentle stirring at $20 \mathrm{~s}$ and $70 \mathrm{~s}$, respectively. Upon the addition of pore-forming monopeptide molecules, the emission of HPTS was immediately monitored at $510 \mathrm{~nm}$ with excitations at both 460 and $403 \mathrm{~nm}$ recorded simultaneously for 300 seconds using fluorescence spectrophotometer (Hitachi, Model F-7100, Japan) after which time an aqueous solution of Triton X-100 (20 $\mu \mathrm{L}, 20 \% \mathrm{v} / \mathrm{v})$ was immediately added to achieve the maximum change in dye fluorescence emission. The final transport trace was obtained as a ratiometric value of $\mathrm{I}_{460} / \mathrm{I}_{403}$ and normalized based on the ratiometric value of $\mathrm{I}_{460} / \mathrm{I}_{403}$ after addition of triton.

\section{The HPTS assay in the presence of FCCP (carbonyl cyanide-4-} (trifluoromethoxy)phenylhydrazone). The HPTS-containing LUV suspension $(25 \mu \mathrm{L}, 2.5$ $\mathrm{mM}$ in $10 \mathrm{mM}$ HEPES buffer containing $100 \mathrm{mM} \mathrm{NaCl}$ at $\mathrm{pH}=7.0$ ) was added to a HEPES buffer solution $(1.93 \mathrm{~mL}, 10 \mathrm{mM}$ HEPES, $100 \mathrm{mM} \mathrm{NaCl})$ to create a $\mathrm{pH}$ gradient for ion transport study. A solution of FCCP $(10 \mathrm{pM})$ and $\mathbf{6} \mathbf{L}_{\mathbf{3}} \mathbf{1 0}(4.3 \mathrm{nM})$ in DMSO was then injected into the suspension under gentle stirring at $20 \mathrm{~s}$ and $70 \mathrm{~s}$, respectively. Upon the addition of pore-forming monopeptide molecules, the emission of HPTS was immediately monitored at $510 \mathrm{~nm}$ with excitations at both 460 and $403 \mathrm{~nm}$ recorded simultaneously for 300 seconds using fluorescence spectrophotometer (Hitachi, Model F-7100, Japan). $300 \mathrm{~s}$ later, aqueous solution of Triton X-100 (20 $\mu \mathrm{L}, 20 \% \mathrm{v} / \mathrm{v})$ was immediately added to achieve the maximum change in dye fluorescence emission. The final transport trace was obtained as a ratiometric value of $\mathrm{I}_{460} / \mathrm{I}_{403}$ and normalized based on the ratiometric value of $\mathrm{I}_{460} / \mathrm{I}_{403}$ after addition of triton.

Single channel current measurement in planar lipid bilayers. The chloroform solution of 1,2-diphytanoyl-sn-glycero-3-phosphocholine (diPhyPC, $10 \mathrm{mg} / \mathrm{ml}, 20 \mathrm{uL}$ ) was evaporated using nitrogen gas to form a thin film and re-dissolved in $n$-decane $(8 \mathrm{uL}) .0 .2 \mu \mathrm{L}$ of this $n$ decane solution was injected into the aperture (diameter $=200 \mathrm{um}$ ) of the Delrin ${ }^{\circledR}$ cup (Warner Instruments, Hamden, CT) with the $n$-decane removed using nitrogen gas. In a typical experiment for conductance measurement, both the chamber (cis side) and Delrin cup (trans side) were filled with an aqueous $\mathrm{KCl}$ solution $(1.0 \mathrm{M}, 1.0 \mathrm{~mL}) . \mathrm{Ag}-\mathrm{AgCl}$ electrodes were inserted into the two solutions with the cis chamber grounded. Planar lipid bilayer was formed by painting $0.3 \mu \mathrm{L}$ of the lipid-containing $n$-decane solution around the $n$-decanepretreated aperture. Successful formation of planar lipid bilayers can be established with a capacitance value ranging from 80-120 pF. Samples $\left(\mathbf{6 L}_{\mathbf{3}} \mathbf{1 0}\right)$ in THF $(0.3-1.0 \mu \mathrm{L})$ were added to the cis compartment to reach a final concentration of around $10^{-8} \mathrm{M}$ and the solution was stirred for a few min until a single current trace appeared. These single channel currents were then measured using a Warner BC-535D bilayer clamp amplifier, collected by PatchMaster (HEKA) with a sample interval at $5 \mathrm{kHz}$ and filtered with an 8-pole Bessel filter at $1 \mathrm{kHz}$ (HEKA). The data were analysed by FitMaster (HEKA) with a digital filter at $100 \mathrm{~Hz}$. Plotting current trace vs voltage yielded chloride conductance $\left(\gamma_{\mathrm{Cl}}\right)$. 
The HPTS assay for anion selectivity. The HPTS-containing LUV suspension $(25 \mu \mathrm{L}, 2.5$ $\mathrm{mM}$ in $10 \mathrm{mM}$ HEPES buffer containing $100 \mathrm{mM} \mathrm{NaX}$ where $\mathrm{X}^{-}=\mathrm{Cl}^{-}, \mathrm{Br}^{-}, \mathrm{I}^{-}, \mathrm{NO}_{3}{ }^{-}$and $\mathrm{ClO}_{4}{ }^{-}$ at $\mathrm{pH}=7.0)$ was added to a HEPES buffer solution $(1.93 \mathrm{~mL}, 10 \mathrm{mM}$ HEPES, $100 \mathrm{mM} \mathrm{NaX}$, where $\mathrm{X}^{-}=\mathrm{Cl}^{-}, \mathrm{Br}^{-}, \mathrm{I}^{-}, \mathrm{NO}_{3}{ }^{-}$and $\mathrm{ClO}_{4}{ }^{-}$at $\mathrm{pH}=8.0$ ) to create a $\mathrm{pH}$ gradient for ion transport study. A solution of peptides at specified concentrations in DMSO was then injected into the LUV suspension under gentle stirring. Upon the addition of pore-forming monopeptide molecules, the emission of HPTS was immediately monitored at $510 \mathrm{~nm}$ with excitations at both 460 and $403 \mathrm{~nm}$ recorded simultaneously for 300 seconds using fluorescence spectrophotometer (Hitachi, Model F-7100, Japan) after which time an aqueous solution of Triton X-100 $(20 \mu \mathrm{L}, 20 \% \mathrm{v} / \mathrm{v})$ was immediately added to achieve the maximum change in dye fluorescence emission. The final transport trace was obtained as a ratiometric value of $\mathrm{I}_{460} / \mathrm{I}_{403}$ and normalized based on the ratiometric value of $\mathrm{I}_{460} / \mathrm{I}_{403}$ after addition of triton. 
EC $_{50}$ determination using the HPTS assay
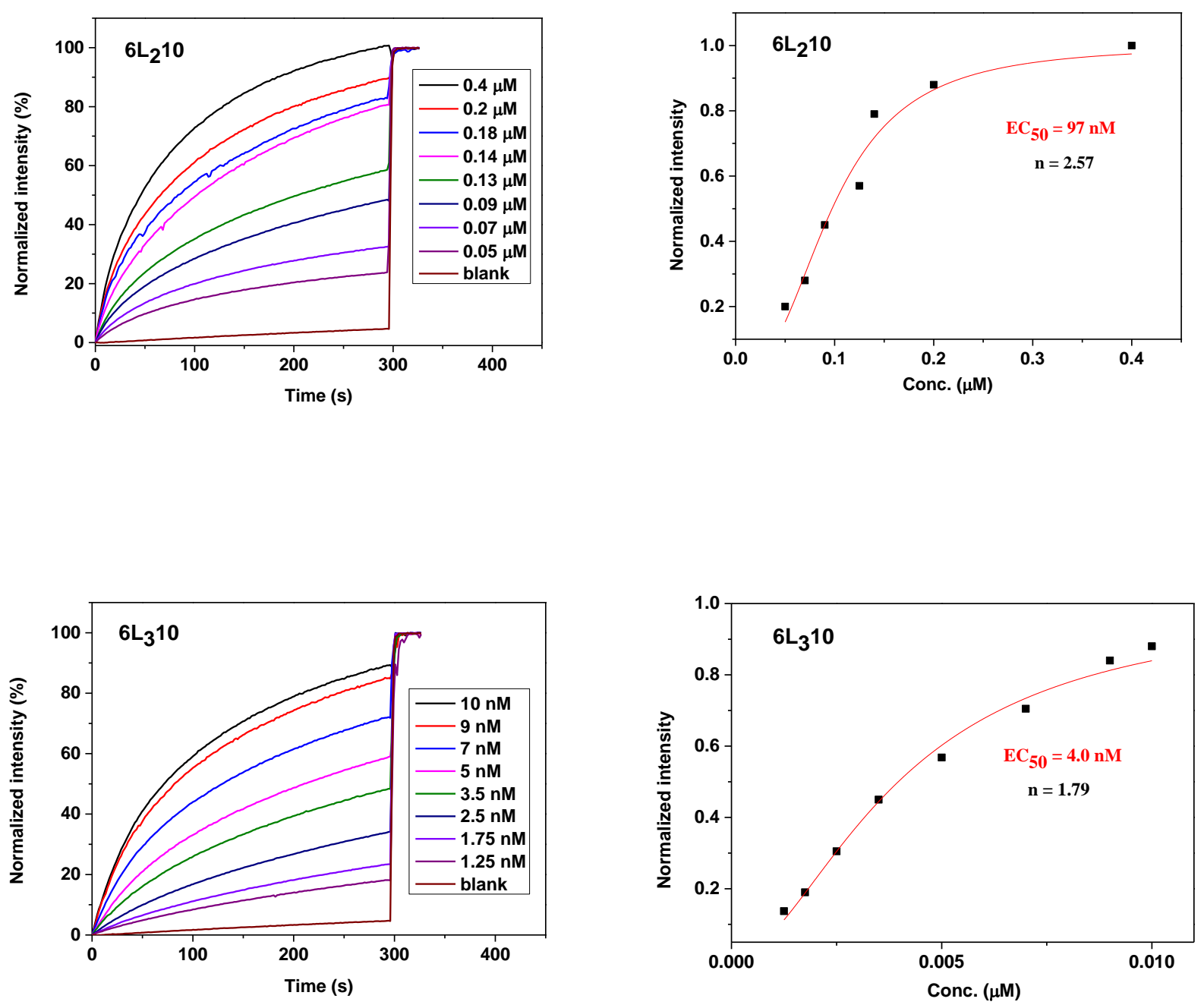

Figure S1. Determination of $E C_{50}$ values for $\mathrm{Cl}^{-}$anions using the ratiometric values of I460/I403 at different concentrations as a function of time for $\mathbf{6} \mathbf{L}_{2} \mathbf{1 0}$ and $\mathbf{6} \mathbf{L}_{\mathbf{3}} \mathbf{1 0}$. 
<smiles>CC(C)(C)C(=O)O</smiles>

\section{Structure of CF dye comprising}

5 -carboxyfluorescein

and

6-carboxyfluorescein
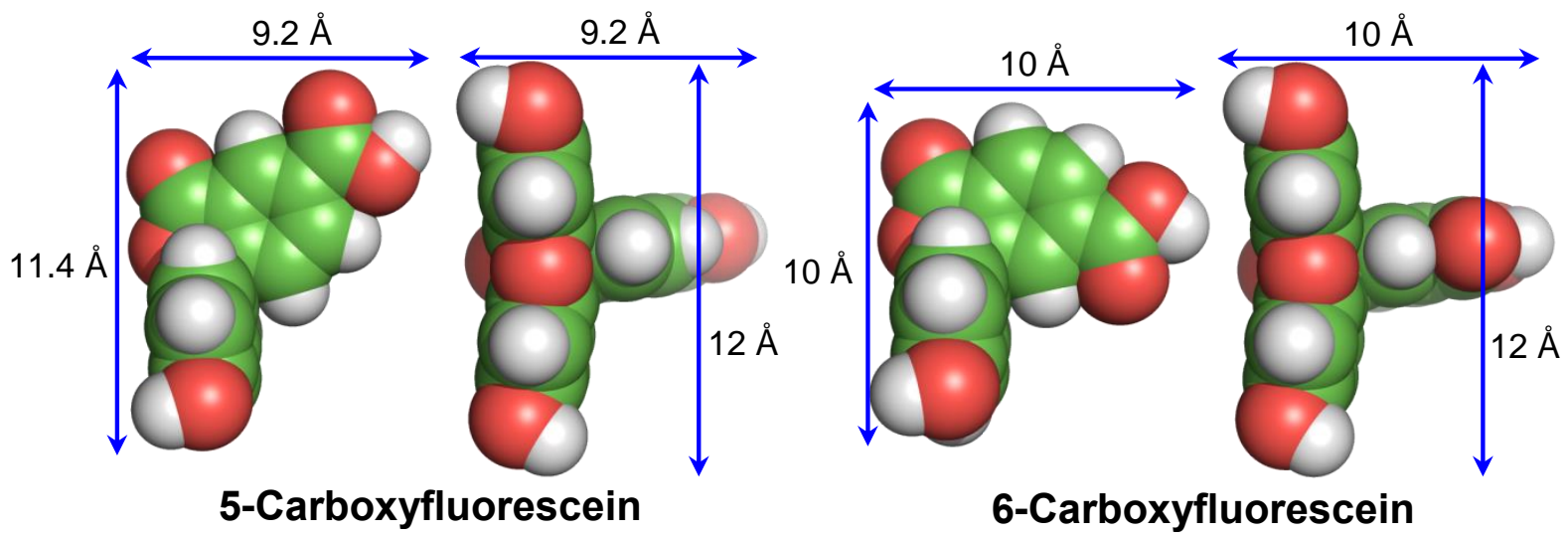

Figure S2. Dimensions of self-quenching CF dyes that consist of a pair of isomers 5carboxyfluorescein and 6-carboxyfluorescein.

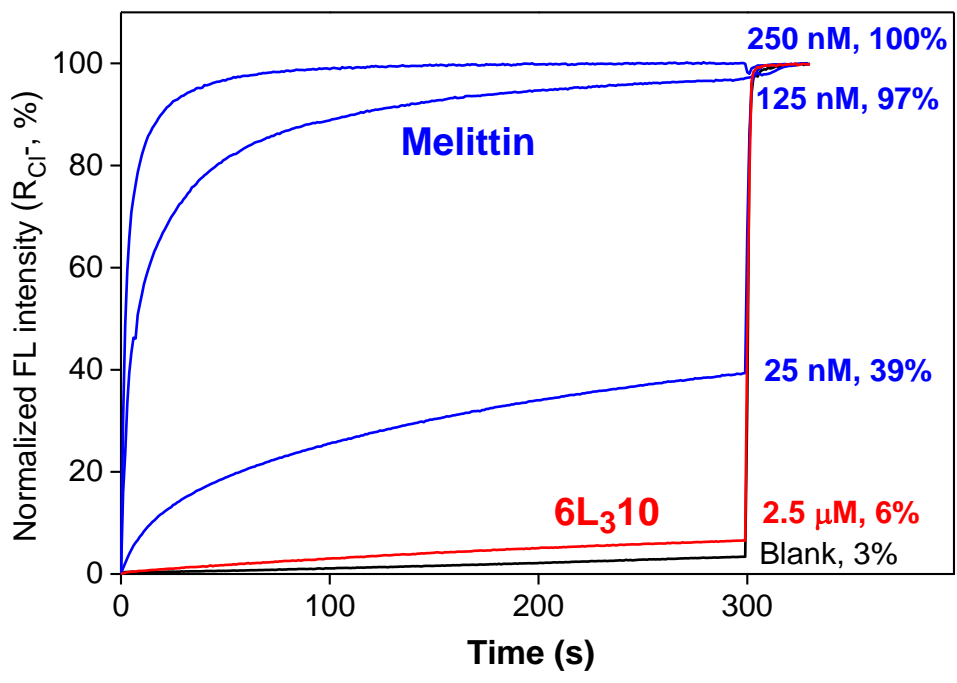

Figure S3. Changes in fluorescence intensity of CF dyes in the presence of melittin and $6 \mathbf{L}_{3} \mathbf{1 0}$ at different concentrations. 
(a)
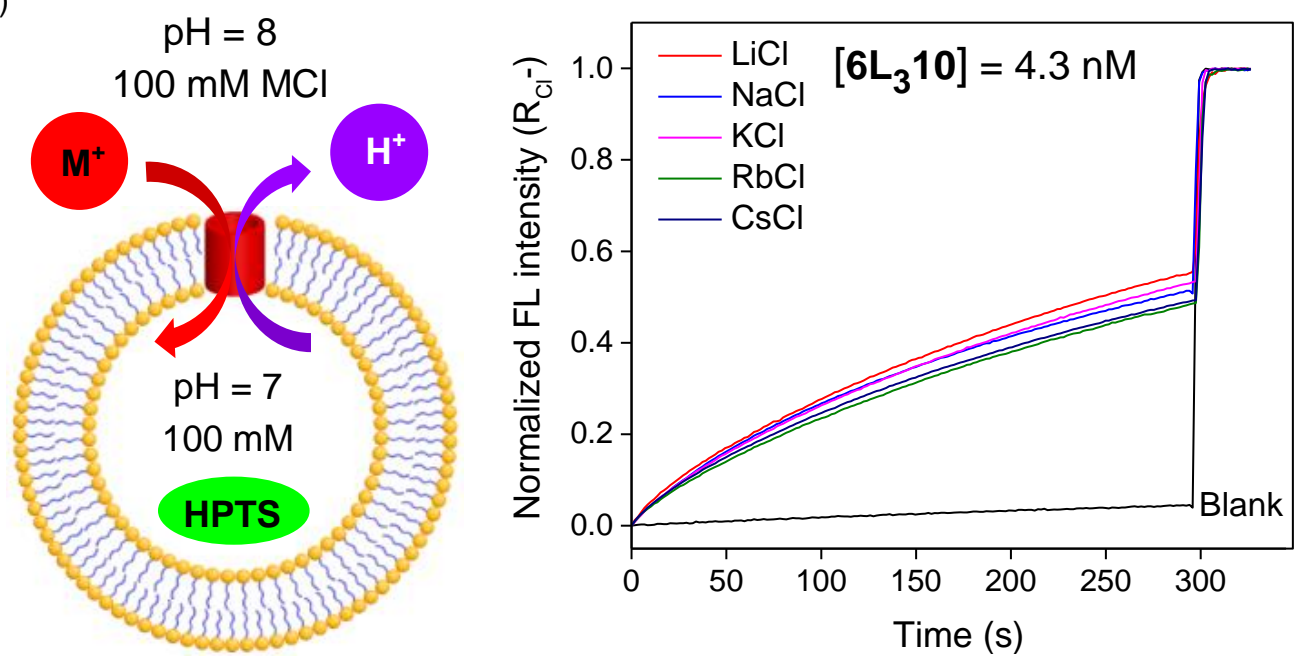

(b)
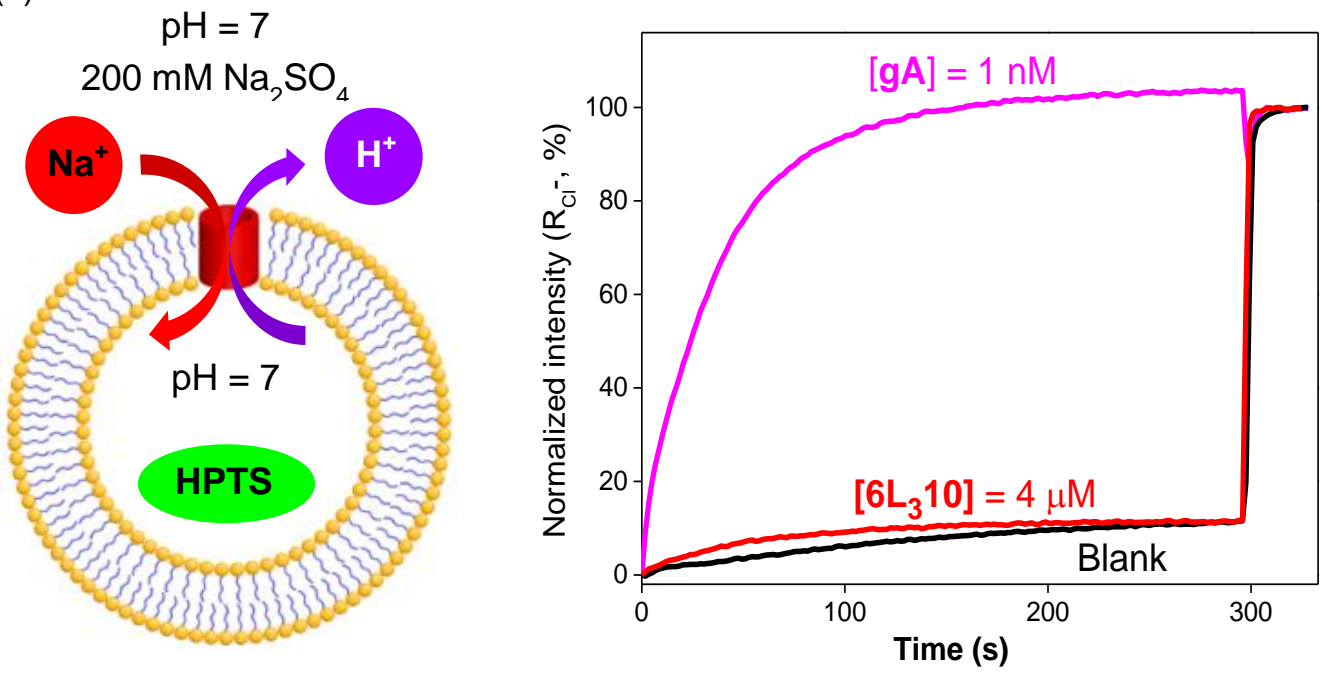

Figure S4. Elucidating ion transport mechanism and species for $\mathbf{6} \mathbf{L}_{\mathbf{3}} \mathbf{1 0}$. 

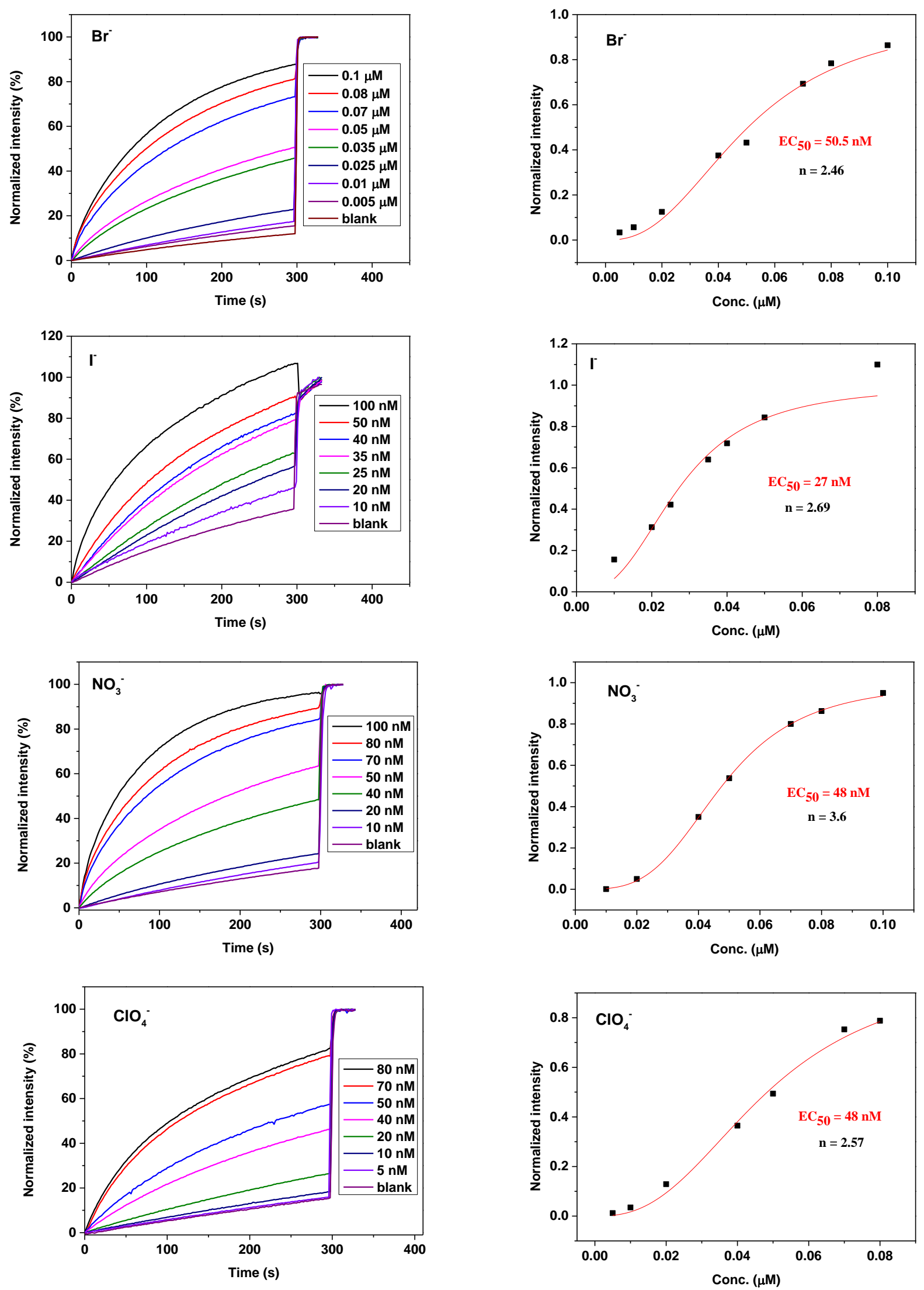

Figure S5. Determination of $E C_{50}$ values for $\mathrm{Br}^{-}, \mathrm{I}^{-}, \mathrm{NO}_{3}{ }^{-}$and $\mathrm{ClO}_{4}{ }^{-}$using the ratiometric values of I460/I403 at different concentrations as a function of time for $\mathbf{6} \mathbf{L}_{\mathbf{2}} \mathbf{1 0}$. 

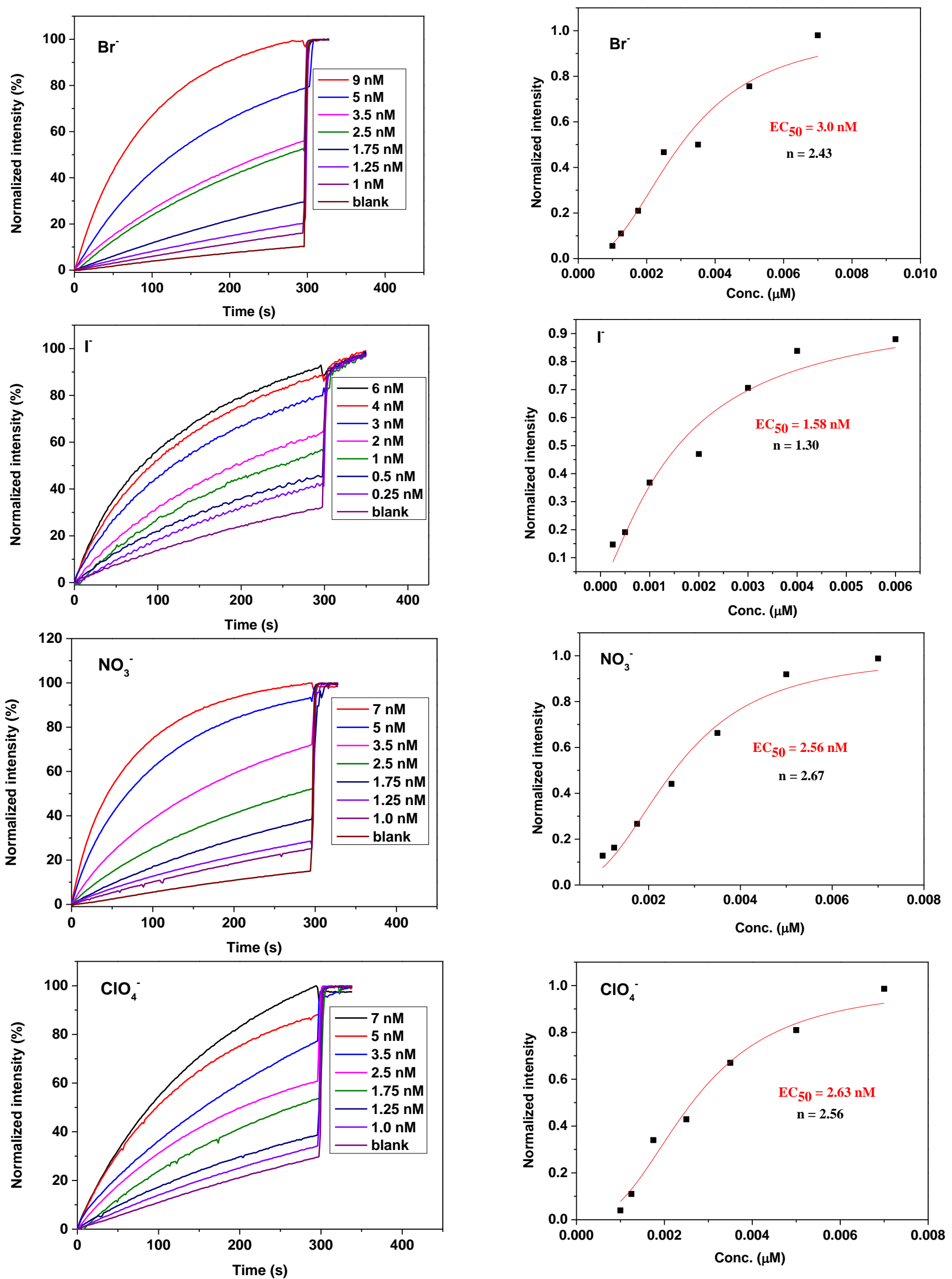

Figure S6. Determination of $E C_{50}$ values for $\mathrm{Br}^{-}, \mathrm{I}^{-}, \mathrm{NO}_{3}{ }^{-}$and $\mathrm{ClO}_{4}{ }^{-}$using the ratiometric values of I460/I403 at different concentrations as a function of time for $\mathbf{6} \mathbf{L}_{\mathbf{3}} \mathbf{1 0}$. 
Molecular modeling using the COMPASS force field. The COMPASS force field (condensed-phase optimized molecular potentials for atomistic simulation studies) developed by Sun $^{1}$ was used to optimize the geometry and to calculate the energy of all molecules. The COMPASS force field is based on state-of-the-art $a b$ initio and empirical parameterization techniques with the valence parameters and atomic partial charges supported by $a b$ initio data, and the van der Waals (vdW) parameters derived by fitting the experimental data of cohesive energies and equilibrium densities. The convergence tolerance is $2 \times 10^{-5} \mathrm{kcal} / \mathrm{mol}$ for the energy, $0.001 \mathrm{kcal} / \mathrm{mol} / \AA$ for the force, $0.001 \mathrm{GPa}$ for the stress, and $10^{-5} \AA$ for the displacement. The Ewald method is used for calculating the electrostatic and the van der Waals terms. The accuracy is $10^{-5} \mathrm{kcal} / \mathrm{mol}$. The repulsive cutoff is $6 \AA$ for the van der Waals term. For the periodical structure, the box vector along the stacking direction is also optimized together with the molecules.

Molecular dynamics simulation: In our current study, we believe formation of a barrel stave-like pore requires at least three 1D structures. Given that the interchain separation distance in $\mathrm{H}$-bonded 1D structure involving $\mathbf{6} \mathbf{L}_{\mathbf{3}} \mathbf{1 0}$ is $\sim 4.8 \AA$, six molecules of $6 \mathbf{L}_{3} 10$ should be sufficient to fully span the hydrophobic thickness of $28.1 \AA$ in POPC membrane. ${ }^{2}$ On this basis, molecular dynamics (MD) simulation of four barrel-stave ensembles, which consist of three to six 1D structures that each is made up of six molecules of $\mathbf{6} \mathbf{L}_{\mathbf{3}} \mathbf{1 0}$, were carried out in POPC membrane (Figure 5). Since each 1D structure carries five groups of well-aligned side chains, every oligomeric barrel-stave ensemble can have a great number of different forms as a result of many different types of interaction modes among the constituent 1D structures. Among so many different forms, we reasoned that the ensembles, having as many as possible their shortest branched side chains (e.g., iso-butyl chains) point to the pore interior, might be the most likely ones that may form a sizable pore. This reasoning is based on our perspectives that the longer and flexible hexyl and decyl chains, when exposed to the interior, can easily fill the interior empty space and thus may not favor the pore formation. But when exposed to the exterior, they may enhance the associative interactions between 1D structures and between oligomeric ensembles and the surrounding hydrophobic lipid tails, and thus stabilize the structure of pore-containing ensembles.

In line with the above hypothesis, we constructed trimeric, tetrameric, pentamric and hexameric ensembles using $1 \mathrm{D}$ structure of $\left(\mathbf{6} \mathbf{L}_{\mathbf{3}} \mathbf{1 0}\right)_{6}$ computationally optimized using the COMPASS force field (Figure 5a). ${ }^{1}$ Each ensemble contains two subensembles that differ only by how the constituent 1D structures interact with each other. For example, the representative tetrameric sub-ensemble $\left[\left(\mathbf{6 L}_{3} \mathbf{1 0}\right)_{6}\right]_{4}$ (Figure $5 b$ ) is formed as a result of the associative interactions among hexyl and decyl side chains from the two neighboring 1D structures. Alternatively, the interactions between hexyl and hexyl side chains and between decyl and decyl side chains among the two 
neighboring 1D structures can also be used to mediate the formation of another tetrameric sub-ensemble having the same formula of $\left[\left(\mathbf{6} \mathbf{L}_{\mathbf{3}} \mathbf{1 0}\right)_{6}\right]_{4}$.

These eight ensembles were then embedded in a bilayer, having a dimension of 70 $\AA$ (w) x $70 \AA$ (w) x $74 \AA$ (h) that comprises 128 POPC molecules and 2 x 2397 water molecules (Figure $5 b$ ). This simulation system was subjected to standard molecular dynamics (MD) simulation using the CHARMM program, ${ }^{3}$ PME method ${ }^{4}$ and SHAKE algorithm. ${ }^{5}$ Among these eight MD-simulated structures, only one tetrameric ensemble $\left[\left(\mathbf{6} \mathbf{L}_{3} \mathbf{1 0}\right)_{6}\right]_{4}$ ends up with a sizable pore (Figure $5 \mathrm{c}$ ). A quick look into all four 1D structures in the tetrameric ensemble reveals persistent formation of all intermolecular H-bonds that are supposed to form among 24 molecules of $6 \mathbf{L}_{\mathbf{3}} \mathbf{1 0}$. But we wish to emphasize here that the actual pore size, number of H-bonded 1D structures required to form pores and association modes among these 1D structures might differ from the MD result. Nevertheless, these results do demonstrate the importance and reliability of intermolecular H-bonds in producing sufficiently long $\mathrm{H}$-bonded 1D structures for spanning the entire hydrophobic membrane region. They also suggest high appropriateness of applying the barrel-stave model to account for anion conduction by structurally extremely simple short peptides such as $\mathbf{6} \mathbf{L}_{\mathbf{3}} \mathbf{1 0}$, which carries no sophisticated functional groups for anion binding and transporting.

\section{References}

1. H. B. Sun, J. Phys. Chem. B, 1998, 102, 7338-7364.

2. C. L. Ren, X. Ding, A. Roy, J. Shen, S. Zhou, F. Chen, S. F. Yau Li, H. Ren, Y. Y. Yang and H. Q. Zeng, Chem. Sci., 2018, 9, 4044.

3. (a) S. Jo, T. Kim, V. G. Iyer and W. Im, J. Comput. Chem., 2008, 29, 1859; (b) E. L. Wu, X. Cheng, S. Jo, H. Rui, K. C. Song, E. M. Davila-Contreras, Y. Qi, J. Lee, V. Monje-Galvan, R. M. Venable, J. B. Klauda and W. Im, J. Comput. Chem., 2014, 35, 1997; (c) S. Jo, J. B. Lim, J. B. Klauda and W. Im, Biophys. J., 2009, 97, 50; (d) K. Vanommeslaeghe, E. Hatcher, C. Acharya, S. Kundu, S. Zhong, J. Shim, E. Darian, O. Guvench, P. Lopes, I. Vorobyov and A. D. MacKerell, J. Comput. Chem., 2010, 31, 671; (e) W. L. Jorgensen, J. Chandrasekhar, J. D. Madura, R. W. Impey and M. L. Klein, J. Chem. Phys., 1983, 79, 926.

4. U. Essmann, L. Perera, M. L. Berkowitz, T. Darden, H. Lee and L. G. Pedersen, J. Chem. Phys., 1995, 103, 8577.

5. G. J. Martyna, D. J. Tobias and M. L. Klein, J. Chem. Phys., 1994, 101, 4177. 


\section{${ }^{1}$ HNMR and ${ }^{13} \mathrm{C}$ NMR}

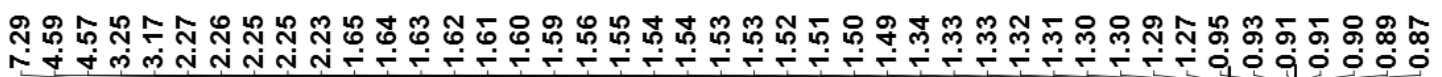
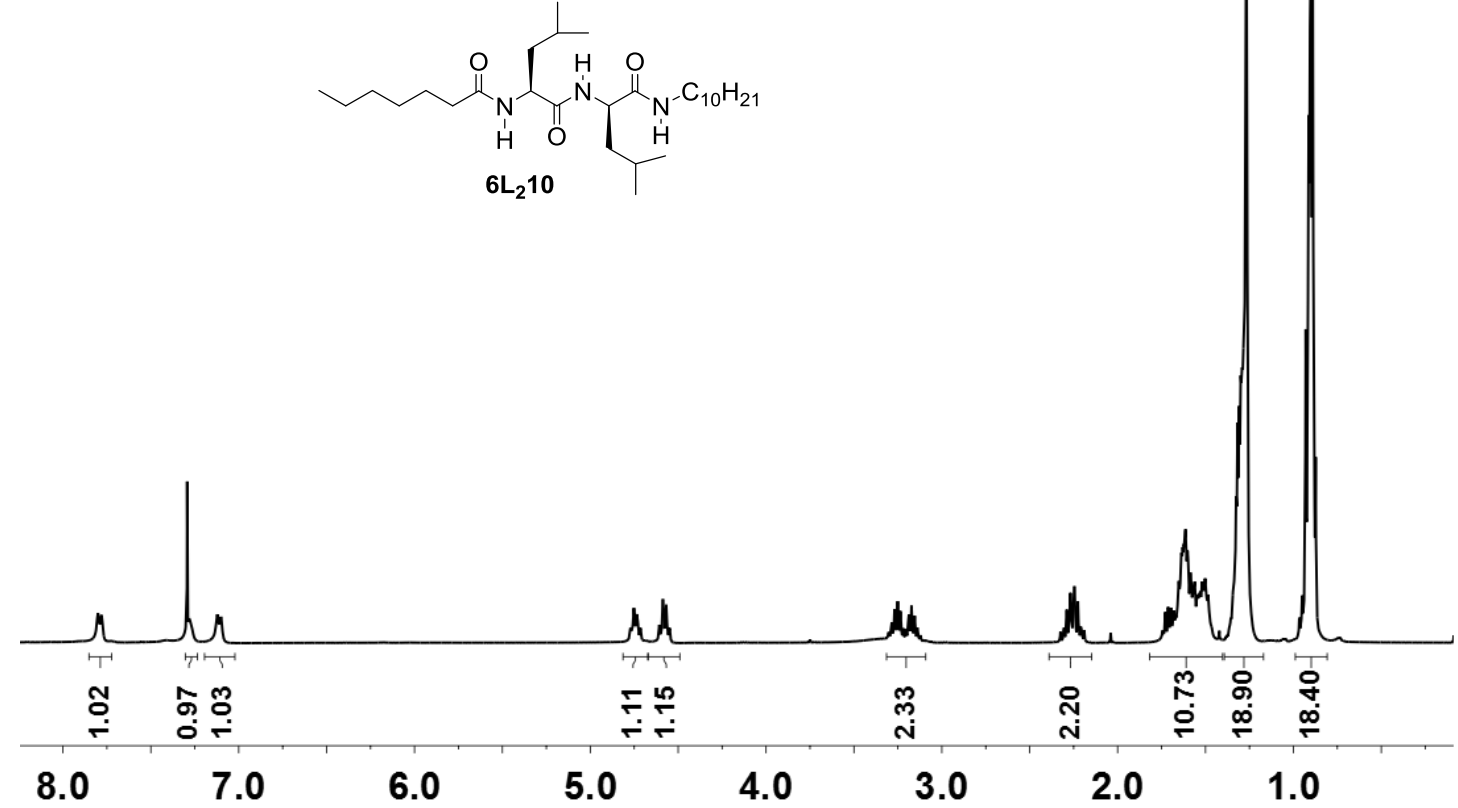

نำ

あ ติ

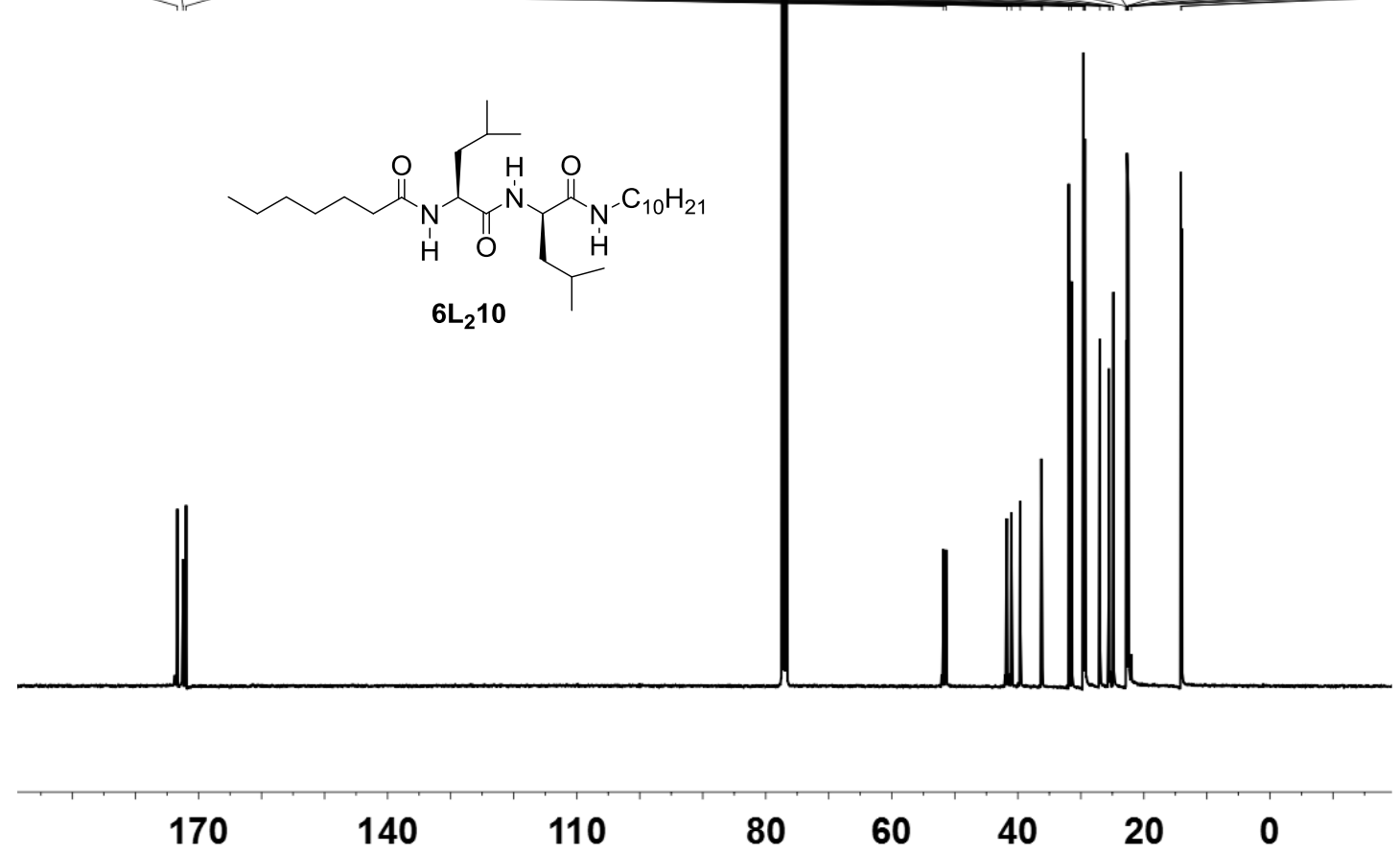




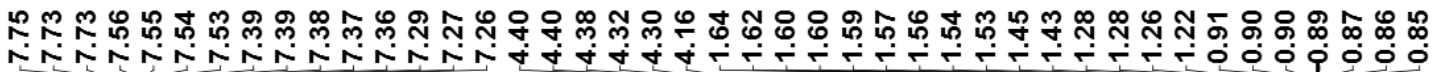

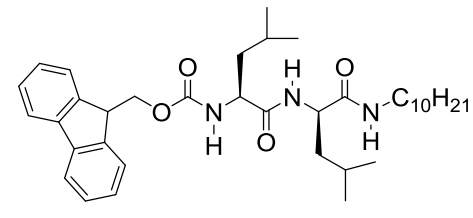

Fmoc- $\mathrm{L}_{2}-10$

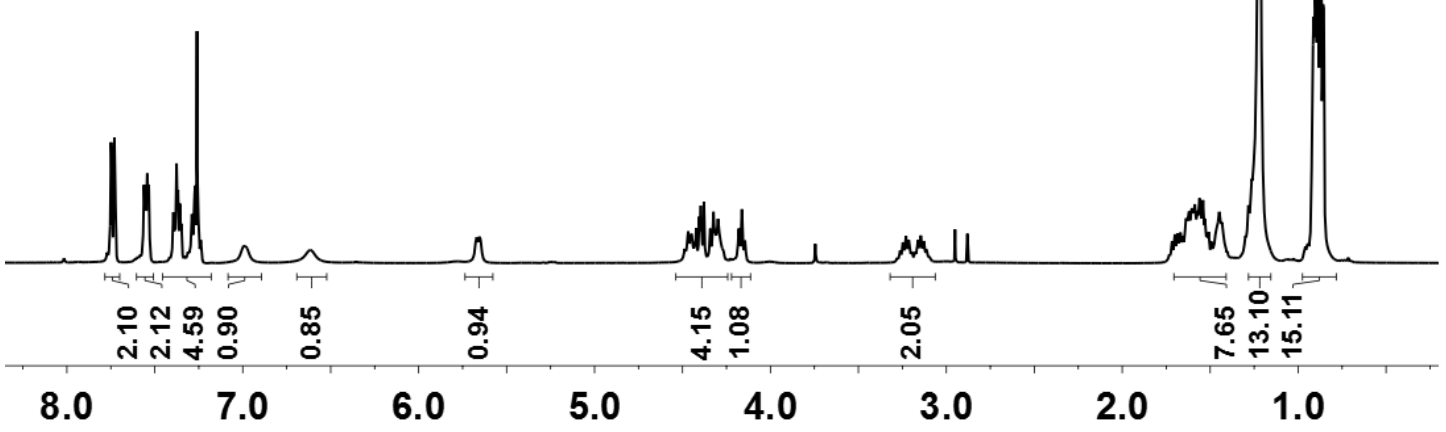

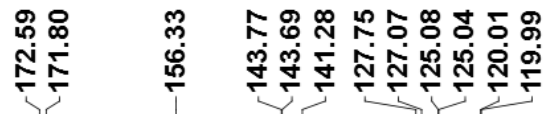

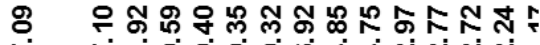

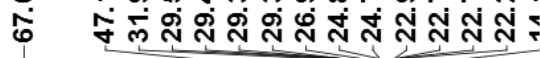

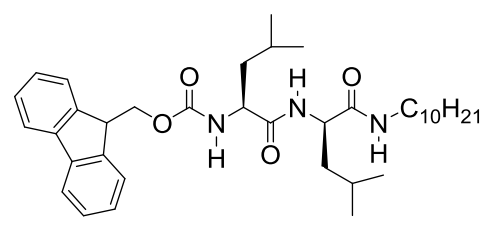

Fmoc- $\mathbf{L}_{2}-10$

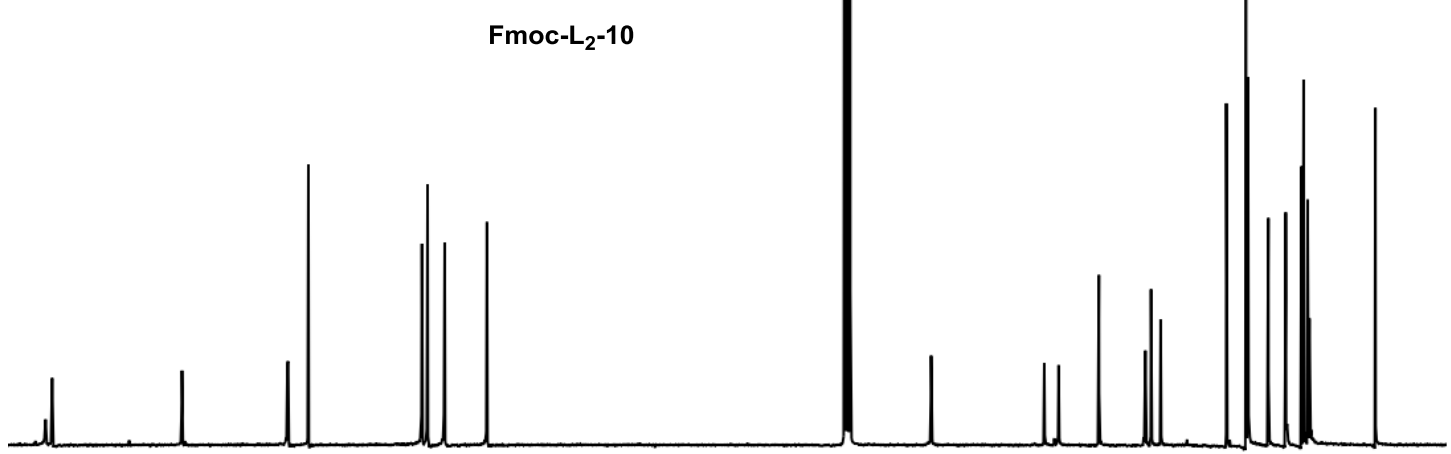

160

140

120

100

80

60

40

20 


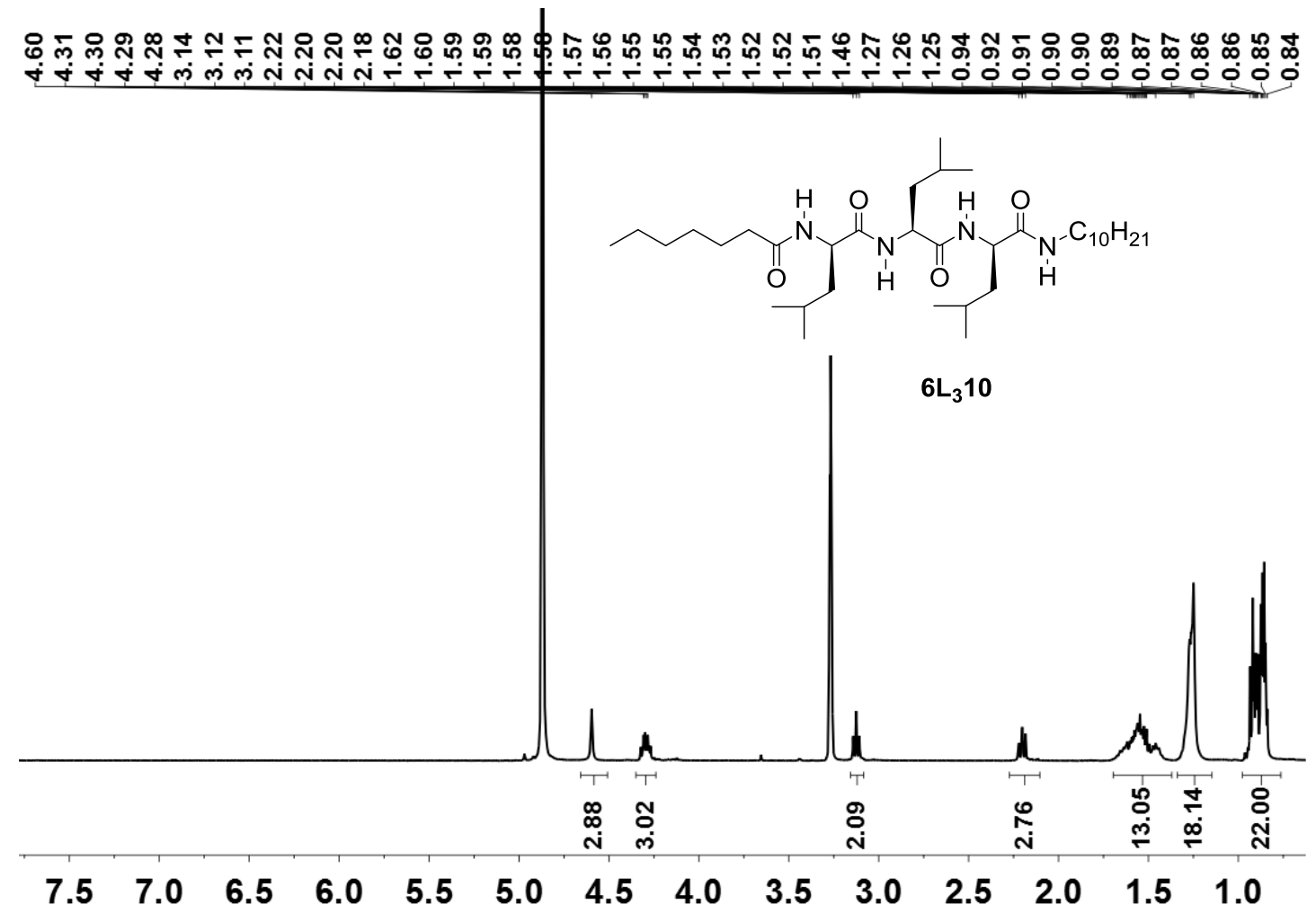

눙 웅

$\stackrel{5}{\frac{5}{5}}$

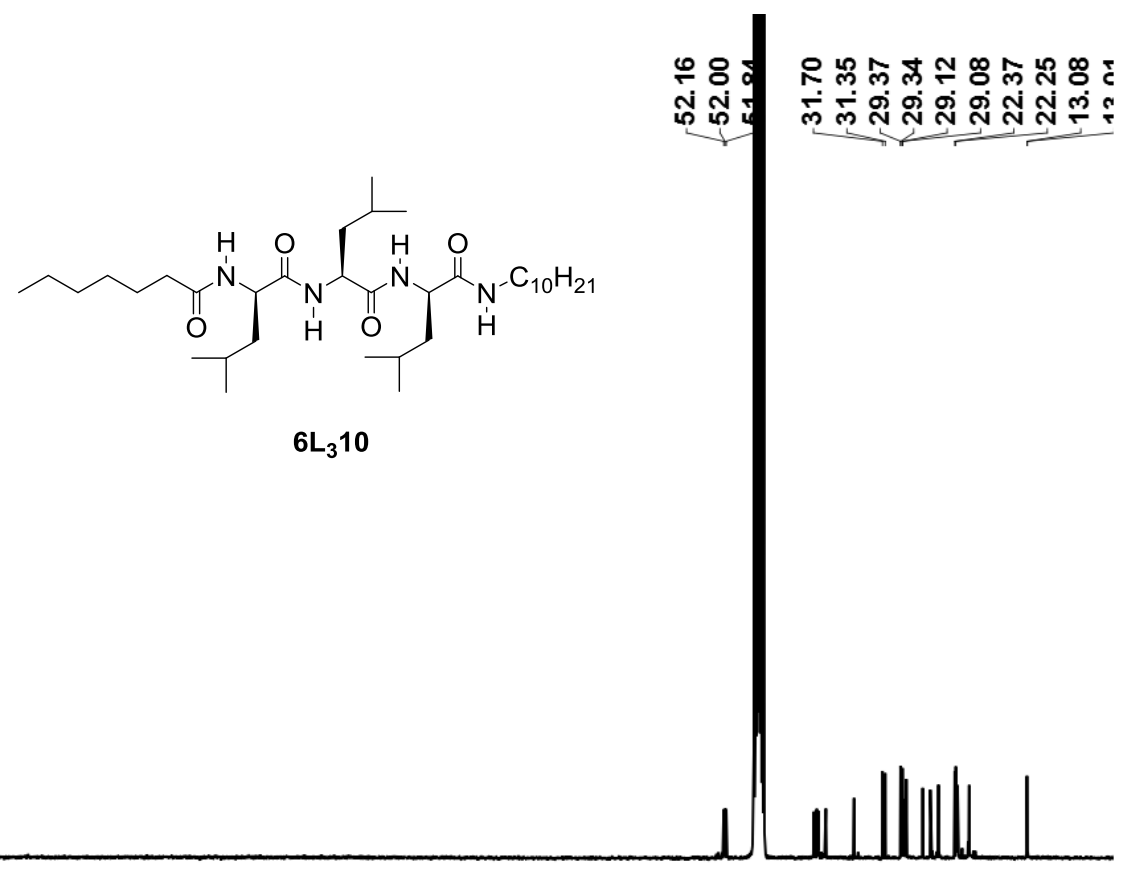

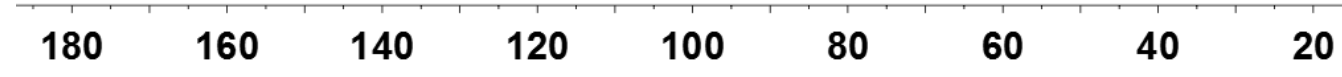

